\title{
Geospatial literacy in Africa-Nigeria
}

\author{
Raimi Abidemi Asiyanbola ${ }^{\text {a }}$ \\ ${ }^{a}$ Department of Geography, Faculty of Social Sciences, Osun State University, Nigeria; rasiyanbola@ gmail.com
}

\begin{abstract}
Literature reveals that geography has always been a critical type of information that humans - infact all animals - collect, organize, and use, and that place-based information is vital to survival on our planet. Geographic literacy is defined as the ability to apply geographic skills and understanding in personal and civic lives. The growing interest has been sparked by an understanding of the role that spatial literacy plays in implementation of geospatial technologies such as computer, cell phone, internet, geographic information systems (GIS), remote sensing, and global positioning systems (GPS). These technologies are fundamentally changing how we see the world and interact with it. This paper examines geospatial literacy, with reference to people's awareness and use of geospatial literacy aid technologies in Ibadan metropolitan area, Nigeria. The research questions that the paper addresses include the following: How are people's knowledge of computer, cell phone and internet? How are people's awareness of geospatial literacy aid technologies? How are people using geospatial literacy aid technologies? Are people interested in learning more on how to use geospatial literacy aid technologies? What are the challenges confronting the people? The data used in the paper was from administration of 152 questionnaires to civil servants in five local governments in Ibadan metropolitan area and at the Oyo State Government Secretariat in Ibadan, Oyo State, Nigeria between February and August, 2017. Descriptive statistics are used to analyse the data. Policy implications of the findings towards improving human capacity building in geospatial literacy aid technologies were discussed in the paper.
\end{abstract}

Keywords: geospatial literacy, geospatial technologies, Africa, Nigeria

\section{Introduction}

According to Dangermond, (2011), geography has always been a critical type of information that humans - infact all animals - collect, organize, and use, and that place-based information is vital to survival on our planet. Edelson in an article on "The challenges of defining Geo-Literacy" note that geo literacy is preparation for making geographic decisions such as decisions about location or transportation; and far-reaching decisions which are decisions that have remote consequences. He stated that geo literacy requires three abilities: the first is the ability to reason about human systems, environmental systems, and human-environment interactions. The second is the ability to reason about geography, and the third is the ability to reason through decisions systematically. According to him phrases like reasoning about systems, geographic reasoning, and systematic decision making do not convey much meaning to people who have never been taught those skills. He argued that the reason modern societies need to provide their citizens with geo education is the big cost that people pay individually and collectively for geo-illiteracy. In another article written by Edelson on Geographic Literacy in U.S. by 2025 "Geo Learning” he argued that knowing geographical facts does little good if you cannot do something with those facts. According to Edelson people do not need to know geography, they need to be able to do geography. He stated that doing geography is what geographic literacy is all about; and that we should aspire to having all people be able to conduct basic geographic analysis in order to make sound personal, political and professional decisions. He defined geographic literacy as the ability of people to apply geographic skills and understanding in their personal and civic lives. In our contemporary world geospatial technologies has advanced to aid individuals in applying geographic skills and understanding. These technologies include computer, cell phone, internet, geographic information systems (GIS), remote sensing, and global positioning systems (GPS). These technologies are fundamentally changing how we see the world and interact with it (Bednarz and Kemp, 2011).

\section{Literature review}

The term "geo literacy" or "spatial literacy" has not clearly been distinguished in the literature from spatial thinking which Wakabayashi and Ishikawa, (2011) defined as the individual's abilities or attitudes to think spatially in an appropriate way. Bednarz and Kemp (2011) presume that spatial literacy is the outcome of spatial thinking and reasoning, they argued that if one can think and reason in, with, and about space, one can be considered spatially literate. They identified spatial literacy as the ability of an individual to capture and communicate knowledge in the form of a map, understand and recognize the world as viewed from above, recognize and interpret patterns, know that geography is more than just a list of places on the Earth's surface, see the value of geography as a basis for organizing and discovering information, and comprehend such basic concepts as scale and spatial resolution. The National Research Council in the United States (NRC) 
points out that spatial literate students have the following characteristics: they have the habit of mind of thinking spatially, they practice spatial thinking in an informed way, and they adopt a critical stance to spatial thinking (NRC, 2006; Wakabayashi and Ishikawa, 2011).

Bednarz and Kemp (2011) observed that there is a growing recognition that spatial literacy is as important as mathematical literacy (numeracy) and classic literacy - the ability to read and write. The US National Academy of Sciences found that spatial thinking, a key component of spatial literacy ".....is at the heart of many great discoveries in science, that it underpins many of the activities of the modern workforce, and that it pervades the everyday activities of modern life" (NRC, 2006). They also observed that spatial literacy is a component of many professions and careers, ranging from architecture and engineering, to air traffic control, medicine and the arts; and, to geographers and other scholars engaged in "the spatial turn, "being able to think in, with, and through space, that is, to be spatially proficient, is increasingly valuable and generative. They note that the burgeoning interest in spatial literacy has been sparked by an understanding of the role that it plays in the implementation of geospatial technologies such as geographic information systems (GIS), remote sensing, and global positioning systems (GPS) (Bednarz and Kemp, 2011). According to them, these technologies are fundamentally changing how we see the world and interact with it. They argued that, considering these trends, to the general public, spatial literacy may be a new educational essential-an addition to the three "Rs - reading, writing, and rithmatic (Bednarz and Kemp, 2011). Wakabayashi and Ishikawa (2011) note that skills in spatial thinking are acquired not only at schools but also through everyday life. Bednarz and Kemp (2011) note that as location matters more and more with improvements in location-based devices and services, spatial literacy is becoming tightly linked with citizenship. They argued that the geospatiallyaided citizen is a growing tool for positive and productive engagement with improving and managing society. They note that social media with a spatial component is becoming commonplace, and, also, public attention and excitement has been captured by online maps such as Bing Maps, and Google Earth, and by location-based systems that use geographic information to help people undertake spatial activities like find nearby restaurants or meet with friends at a specific place. This, they argued, has inspired new enthusiasm for maps as a form of entertainment and awareness of spatial literacy and that citizens are now both the producers and consumers of geographic information (Bednarz and Kemp, 2011).

Bednarz and Kemp (2011) observed five important understandings about the development of spatial thinking and reasoning, therefore, the foundations of spatial literacy. First, that individual characteristics matter. According to Bednarz and Kemp (2011) research in spatial thinking and reasoning conducted by cognitive scientists, psychologists, and geographers confirm that spatial skills develop uniquely in individuals, and that characteristics of individuals such as sex, experience, age, culture, and education all play a role in spatial literacy. Second, that context matters. According to them, research has confirmed that expertise develops in specific contexts (including disciplinary contexts) and that its transfer from one area to another is not automatic. Third, that scale matters. They argued that it is important to acknowledge the role that scale plays in spatial thinking and spatial literacy; that, there appears to be differences between large scale and small scale spatial thinking. Fourth, that tasks analysis and alignment matters. They argued that it is essential to analyse spatial tasks related to spatial literacy and activities using the typology of the types of spatial thinking (thinking in space, about space, or with space) for two reasons: to make clear the kinds of experiences that will promote varying skills and to understand the roles that individual differences play in spatial thinking. Fifth, that teaching matters. They argued that spatial thinking can, and should be learned by all, thus laying the foundation for spatial literacy. They argued that, there is also the recognition of a continuum from an individual developing spatial literate to a fully competent and expert spatial literate (Bednarz and Kemp, 2011). Wakabayashi and Ishikawa, (2011) note that the need for the teaching and learning of spatial thinking has increased with the rapid growth and widespread use of geospatial technologies. They also note that spatial thinking affords the conceptual foundation of GIScience and increases the applicability of GIS to teaching and learning spatial thinking (Wakabayashi and Ishikawa, 2011).

In Nigeria, empirical study of geospatial literacy is rare. This study is an addition to the literature. The study empirically examines geospatial literacy with reference to the awareness and use of geospatial literacy aid technologies by the people who are government workers in Ibadan metropolitan area of Oyo State, Nigeria. The research questions that the paper addresses are: How are peoples' knowledge of computer, cell phone and internet? How are peoples' awareness of geospatial literacy aid technologies? How are people using geospatial literacy aid technologies? Are people interested in learning more about the use of geospatial literacy aid technologies? What are the challenges confronting the people?

\section{Method of the study}

The data used in the study was obtained from primary and secondary sources. The primary data was collected through administration of questionnaires. The questionnaires were used to collect information from the people who were government workers on their awareness and use of geospatial literacy aid technologies (computer, cell phone, internet, maps, GPS [Global Positioning System], GIS [Geographical Information Systems]) in Ibadan, Oyo State, Nigeria. A total of one hundred and fifty-two (152) questionnaires were administered in five local governments in Ibadan metropolitan area and at the Oyo State Government Secretariat in Ibadan between February and August, 2017. Frequency analysis and descriptive statistics was used to analyse the data. 


\section{Findings of the study}

4.1 Peoples' knowledge of computer, cell phone and internet

Table 1 shows the peoples' knowledge of computer, cell phone and the internet. The table shows that majority of the people interviewed were computer literate $(84.0 \%)$ and have personal computer/Laptop $(69.0 \%)$. Some of them (27.0\%) have been using personal computer/Laptop for 6 - 10 years, $22.0 \%$ of them have been using personal computer/Laptop for $1-5$ years, $16.0 \%$ of them have been using personal computer/Laptop for less than one year, and $5.0 \%$ of them have been using personal computer/Laptop for more than 10 years. Most of them used their personal computer/Laptop for word processing (typing) purpose $(68.0 \%)$ and to browse the internet $(55.0 \%)$. Majority $(76.0 \%)$ of them said that they know how to browse the internet with the personal computer/Laptop. Also majority of them said that they have cell phone $(84.0 \%)$. Some of them $(36.0 \%)$ have been using cell phone for more than 10 years, $27.0 \%$ of them have been using cell phone for 6 10 years, $13.0 \%$ of them have been using cell phone for 1 -5 years, and $14.0 \%$ of them have been using cell phone for less than one year. Majority of them said that they were aware that some cell phone can browse the internet $(90.0 \%)$ and know how to browse the internet with cell phone $(84.0 \%)$ and that they have cell phone that can browse the internet $(83.0 \%)$.

Table 1: Peoples' knowledge of computer, cell phone and the internet

\begin{tabular}{|c|c|c|c|}
\hline $\mathrm{S} / \mathrm{N}$ & Questions & Response & $\begin{array}{l}\% \quad(\mathrm{n} \\
= \\
152)\end{array}$ \\
\hline \multirow[t]{2}{*}{1} & \multirow{2}{*}{$\begin{array}{l}\text { Are you computer } \\
\text { literate? }\end{array}$} & Yes & 84.0 \\
\hline & & No & 15.0 \\
\hline \multirow[t]{2}{*}{2} & \multirow{2}{*}{$\begin{array}{l}\text { Do you have } \\
\text { personal } \\
\text { computer/Laptop? }\end{array}$} & Yes & 68.0 \\
\hline & & No & 31.0 \\
\hline \multirow[t]{4}{*}{3} & \multirow{4}{*}{$\begin{array}{l}\text { How long have you } \\
\text { been using personal } \\
\text { computer/Laptop? }\end{array}$} & $\begin{array}{l}\text { Less than } \\
\text { one year }\end{array}$ & 16.0 \\
\hline & & $1-5$ years & 22.0 \\
\hline & & $6-10$ years & 27.0 \\
\hline & & $\begin{array}{l}\text { More than } \\
10 \text { years }\end{array}$ & 5.0 \\
\hline \multirow[t]{3}{*}{4} & \multirow[t]{3}{*}{$\begin{array}{l}\text { What do you use } \\
\text { your } \\
\text { computer/Laptop to } \\
\text { do? }\end{array}$} & $\begin{array}{l}\text { Word } \\
\text { processing } \\
\text { (Typing) } \\
\text { purposes }\end{array}$ & 68.0 \\
\hline & & $\begin{array}{l}\text { To do } \\
\text { statistical } \\
\text { analysis }\end{array}$ & 28.0 \\
\hline & & $\begin{array}{l}\text { To browse } \\
\text { the internet }\end{array}$ & 55.0 \\
\hline 5 & & Yes & 76.0 \\
\hline
\end{tabular}

\begin{tabular}{|c|c|c|c|}
\hline & $\begin{array}{l}\text { Do you know how to } \\
\text { browse the internet } \\
\text { with personal } \\
\text { computer/Laptops? }\end{array}$ & No & 19.0 \\
\hline \multirow[t]{2}{*}{6} & \multirow{2}{*}{$\begin{array}{l}\text { Do you have a cell } \\
\text { phone? }\end{array}$} & Yes & 84.0 \\
\hline & & No & 11.0 \\
\hline \multirow[t]{4}{*}{7} & \multirow[t]{4}{*}{$\begin{array}{l}\text { How long have you } \\
\text { been using cell } \\
\text { phone? }\end{array}$} & $\begin{array}{ll}\text { Less } & \text { than } \\
\text { one } & \text { year } \\
\text { ago } & \end{array}$ & 14.0 \\
\hline & & $\begin{array}{l}1-5 \text { years } \\
\text { ago }\end{array}$ & 13.0 \\
\hline & & $\begin{array}{l}6-10 \text { years } \\
\text { ago }\end{array}$ & 27.0 \\
\hline & & $\begin{array}{lr}\text { More } & \text { than } \\
10 \text { years } \\
\text { ago }\end{array}$ & 36.0 \\
\hline \multirow[t]{2}{*}{8} & \multirow{2}{*}{$\begin{array}{l}\text { Are you aware that } \\
\text { some cell phones can } \\
\text { browse the internet? }\end{array}$} & Yes & 90.0 \\
\hline & & No & 9.0 \\
\hline \multirow[t]{2}{*}{9} & \multirow{2}{*}{$\begin{array}{l}\text { Do you know how to } \\
\text { browse the internet } \\
\text { with the cell phone? }\end{array}$} & Yes & 84.0 \\
\hline & & No & 15.0 \\
\hline \multirow[t]{2}{*}{10} & \multirow{2}{*}{$\begin{array}{l}\text { Do you have cell } \\
\text { phone that can } \\
\text { browse the internet? }\end{array}$} & Yes & 83.0 \\
\hline & & No & 16.0 \\
\hline
\end{tabular}

4.2 Peoples' awareness of geospatial literacy aid technologies

Table 2 shows the peoples' awareness of geospatial literacy aid technologies. Majority of the people interviewed were aware of maps $(95.0 \%)$, know how to read maps $(80.0 \%)$, aware of the existence of maps on the internet $(74.0 \%)$, and had browsed maps on the internet $(69.0 \%)$. While $14.0 \%$ of them said that they browse maps on the internet daily, $44.0 \%$ of them said that they browse maps on the internet occasionally. The people were asked as to which online maps they were aware of. Most of them said that they were aware of Google Maps (65.0\%), followed by Google Earth (36.0\%), and Bing Maps $(32.0 \%)$. Also most of them were aware of Global Positioning System (GPS) (59.0\%) and the use of GPS $(55.0 \%)$. Furthermore, most of them were aware of Geographical Information Systems (GIS) and Remote Sensing technologies $(62.0 \%)$.

Table 2: Peoples' awareness of geospatial literacy aid technologies

\begin{tabular}{|l|l|l|l|}
\hline S/N & Questions & Response & $\begin{array}{l}\text { \% (n } \\
= \\
152)\end{array}$ \\
\hline 1 & \multirow{2}{*}{$\begin{array}{l}\text { Are you aware of } \\
\text { maps? }\end{array}$} & Yes & 95.0 \\
\cline { 3 - 4 } & \multirow{2}{*}{$\begin{array}{l}\text { Do you know how } \\
\text { to read map? }\end{array}$} & Yes & 5.0 \\
\cline { 3 - 4 } & & No & 80.0 \\
\hline
\end{tabular}




\begin{tabular}{|c|c|c|c|}
\hline \multirow[t]{2}{*}{3} & \multirow{2}{*}{$\begin{array}{l}\text { Do you know } \\
\text { what maps are } \\
\text { used for? }\end{array}$} & Yes & 84.0 \\
\hline & & No & 15.0 \\
\hline \multirow[t]{2}{*}{4} & \multirow{2}{*}{$\begin{array}{l}\text { Are you aware of } \\
\text { existence of maps } \\
\text { on the internet? }\end{array}$} & Yes & 74.0 \\
\hline & & No & 20.0 \\
\hline \multirow[t]{2}{*}{5} & \multirow{2}{*}{$\begin{array}{l}\text { Have you ever } \\
\text { browsed maps on } \\
\text { the internet? }\end{array}$} & Yes & 69.0 \\
\hline & & No & 29.0 \\
\hline \multirow[t]{5}{*}{6} & \multirow{5}{*}{$\begin{array}{l}\text { How often do you } \\
\text { browse map on } \\
\text { the internet? }\end{array}$} & Daily & 14.0 \\
\hline & & Once a week & 8.0 \\
\hline & & Once a month & 6.0 \\
\hline & & Occasionally & 44.0 \\
\hline & & Rarely & 6.0 \\
\hline \multirow[t]{5}{*}{7} & \multirow{5}{*}{$\begin{array}{l}\text { Which online } \\
\text { maps are you } \\
\text { aware of? }\end{array}$} & Google Earth & 36.0 \\
\hline & & Google Maps & 65.0 \\
\hline & & Bing Maps & 32.0 \\
\hline & & None & 15.0 \\
\hline & & No & 12.0 \\
\hline \multirow[t]{2}{*}{8} & \multirow{2}{*}{$\begin{array}{l}\text { Are you aware of } \\
\text { GPS (Global } \\
\text { Positioning } \\
\text { System) } \\
\text { technology? }\end{array}$} & Yes & 59.0 \\
\hline & & No & 34.0 \\
\hline \multirow[t]{2}{*}{9} & \multirow{2}{*}{$\begin{array}{l}\text { Are you aware of } \\
\text { the use of GPS } \\
\text { technology? }\end{array}$} & Yes & 55.0 \\
\hline & & No & 41.0 \\
\hline \multirow[t]{2}{*}{10} & \multirow[b]{2}{*}{$\begin{array}{l}\text { Are you aware of } \\
\text { Geographical } \\
\text { Information } \\
\text { System/Remote } \\
\text { Sensing } \\
\text { technology? }\end{array}$} & Yes & 62.0 \\
\hline & & No & 36.0 \\
\hline
\end{tabular}

Source: Field survey, 2017

\subsection{Peoples' practical application of geospatial literacy aid technologies}

Table 3 shows respondents' practical applications of geospatial literacy aid technologies. The table show that most $(61.0 \%)$ of the respondents use their personal computer/Laptops to search for location on the internet, and $60.0 \%$ of the respondents use their personal computer/Laptops to search for direction to places on the internet. Majority of the respondents had browsed the internet to get location of places (78.0\%), had browsed the internet to get direction to places $(75.0 \%)$, and had browsed the internet to get distance of places $(71.0 \%)$. The respondents were asked what they used their cell phones to do. Majority of them said that they used their cell phones to make phone calls $(89.0 \%)$, and to browse the internet (74.0\%). Some of them also said that they use their cell phone to get location of places $(53.0 \%)$, to get direction to places $(45.0 \%)$, and to get distance to places $(42.0 \%)$. The respondents were asked whether they had ever used map.
The analysis of their responses show that majority of them had used maps $(82.0 \%)$. They were also asked which online maps they had browsed and used. The analysis of their responses show that most of them had browsed and used Google Maps (63.0\%), followed by Bing Maps (27.0\%), and Google Earth (22.0\%). Most of the people interviewed said that they use cell phones to browse maps on the internet $(65.0 \%)$ and also that they use computer/Laptops to browse maps on the internet (60.0\%).

Table 3: Peoples' practical application of geospatial literacy aid technologies

\begin{tabular}{|c|c|c|c|}
\hline $\mathrm{S} / \mathrm{N}$ & Questions & Response & $\begin{array}{l}\% \quad(\mathrm{n} \\
= \\
152)\end{array}$ \\
\hline \multirow[t]{2}{*}{1} & \multirow{2}{*}{$\begin{array}{l}\text { Do you use your } \\
\text { personal } \\
\text { computer/Laptops to } \\
\text { search for location } \\
\text { on the internet? }\end{array}$} & Yes & 61.0 \\
\hline & & No & 30.0 \\
\hline \multirow[t]{2}{*}{2} & \multirow{2}{*}{$\begin{array}{l}\text { Do you use your } \\
\text { personal } \\
\text { computer/Laptops to } \\
\text { search for direction } \\
\text { to places on the } \\
\text { internet? }\end{array}$} & Yes & 60.0 \\
\hline & & No & 30.0 \\
\hline \multirow[t]{2}{*}{3} & \multirow{2}{*}{$\begin{array}{l}\text { Have you ever } \\
\text { browsed the internet } \\
\text { to get location of } \\
\text { places? }\end{array}$} & Yes & 78.0 \\
\hline & & No & 21.0 \\
\hline \multirow[t]{2}{*}{4} & \multirow{2}{*}{$\begin{array}{l}\text { Have you ever } \\
\text { browsed the internet } \\
\text { to get direction to } \\
\text { places? }\end{array}$} & Yes & 75.0 \\
\hline & & No & 22.0 \\
\hline \multirow[t]{2}{*}{5} & \multirow{2}{*}{$\begin{array}{l}\text { Have you ever } \\
\text { browsed the internet } \\
\text { to get distance to } \\
\text { places? }\end{array}$} & Yes & 71.0 \\
\hline & & No & 26.0 \\
\hline \multirow[t]{5}{*}{6} & \multirow{5}{*}{$\begin{array}{l}\text { What do you use } \\
\text { your cell phone to } \\
\text { do? }\end{array}$} & $\begin{array}{l}\text { To make } \\
\text { phone call }\end{array}$ & 89.0 \\
\hline & & $\begin{array}{l}\text { To browse } \\
\text { the internet }\end{array}$ & 74.0 \\
\hline & & $\begin{array}{l}\text { To get } \\
\text { location to } \\
\text { places }\end{array}$ & 53.0 \\
\hline & & $\begin{array}{l}\text { To get } \\
\text { direction } \\
\text { to places }\end{array}$ & 45.0 \\
\hline & & $\begin{array}{l}\text { To get } \\
\text { distances } \\
\text { to places }\end{array}$ & 42.0 \\
\hline \multirow[t]{2}{*}{7} & \multirow{2}{*}{$\begin{array}{l}\text { Have you ever used } \\
\text { maps? }\end{array}$} & Yes & 82.0 \\
\hline & & No & 17.0 \\
\hline
\end{tabular}




\begin{tabular}{|c|c|c|c|}
\hline \multirow[t]{4}{*}{8} & \multirow{4}{*}{$\begin{array}{l}\text { Which online maps } \\
\text { have you browsed } \\
\text { and used? }\end{array}$} & $\begin{array}{l}\text { Google } \\
\text { Earth }\end{array}$ & 22.0 \\
\hline & & $\begin{array}{l}\text { Google } \\
\text { Maps }\end{array}$ & 63.0 \\
\hline & & Bing Maps & 27.0 \\
\hline & & None & 16.0 \\
\hline \multirow[t]{2}{*}{9} & \multirow{2}{*}{$\begin{array}{l}\text { Do you use cell } \\
\text { phone to browse } \\
\text { Maps on the } \\
\text { internet? }\end{array}$} & Yes & 65.0 \\
\hline & & No & 32.0 \\
\hline \multirow[t]{2}{*}{10} & \multirow{2}{*}{$\begin{array}{l}\text { Do you use } \\
\text { computer/Laptops to } \\
\text { browse Maps on the } \\
\text { internet? }\end{array}$} & Yes & 60.0 \\
\hline & & No & 33.0 \\
\hline
\end{tabular}

Source: Field survey, 2017

4.4 Peoples' interest in learning more on using geospatial literacy aid technologies

Table 4 shows the interviewed peoples' interest in learning more on practical application of geospatial literacy aid technologies. The table shows that majority of the respondents had interest to learn more about how to read maps $(80.0 \%)$, to learn how to use GPS technology (78.0\%), to be trained in Geographical Information Systems (GIS)/Remote Sensing (72.0\%), and to be trained in geospatial technologies $(68.0 \%)$. Respondents were asked whether they know where they can be trained. Some of them $(40.0 \%)$ said that they do not know where they can be trained on how to learn more on map reading, $48.0 \%$ said they do not know where they can be trained on the use of GPS technology, 53.0\% said that they do not know where they can be trained on GIS/Remote Sensing, and $53.0 \%$ said that they do not know where they can be trained in geospatial technologies.

Table 5 shows the willingness of the people to pay for the training. The table shows that $68.0 \%$ were willing to pay for the training on how to read maps, $64.0 \%$ were willing to pay for the training on the use of GPS technology, $62.0 \%$ were willing to pay for the training in Geographical Information Systems/Remote Sensing, and 63.0\% were willing to pay for the training in geospatial technologies. These results indicate that most of them were willing to pay for training in geospatial technology.

Table 4: Respondents' interest in learning more on doing geography using geospatial literacy aid technologies

\begin{tabular}{|l|l|l|l|}
\hline S/N & Questions & Response & $\begin{array}{l}\%(\mathrm{n}= \\
152)\end{array}$ \\
\hline 1 & \begin{tabular}{l} 
Do you have \\
interest to learn \\
more how to read \\
\cline { 3 - 4 }
\end{tabular} & Yes & 80.0 \\
\hline 2 & $\begin{array}{l}\text { Dops? you know } \\
\text { where you can be } \\
\text { trained on how to } \\
\text { read Maps? }\end{array}$ & No & 16.0 \\
\hline
\end{tabular}

\begin{tabular}{|c|c|c|c|}
\hline \multirow[t]{2}{*}{3} & \multirow{2}{*}{$\begin{array}{l}\text { Do you } \\
\text { interest to learn } \\
\text { how to use GPS } \\
\text { technology? }\end{array}$} & Yes & 78.0 \\
\hline & & No & 20.0 \\
\hline \multirow[t]{2}{*}{4} & \multirow{2}{*}{$\begin{array}{l}\text { Do you know } \\
\text { where you can be } \\
\text { trained on the use of } \\
\text { GPS technology? }\end{array}$} & Yes & 42.0 \\
\hline & & No & 48.0 \\
\hline \multirow[t]{2}{*}{5} & \multirow[b]{2}{*}{$\begin{array}{l}\text { Do you have } \\
\text { interest to be } \\
\text { trained } \\
\text { Geographical in } \\
\text { Information } \\
\text { System/Remote } \\
\text { Sensing } \\
\text { technology? }\end{array}$} & Yes & 72.0 \\
\hline & & No & 26.0 \\
\hline \multirow[t]{2}{*}{6} & \multirow[b]{2}{*}{$\begin{array}{l}\text { Do you know } \\
\text { where you can be } \\
\text { trained } \\
\text { Geographical in } \\
\text { Information } \\
\text { System/Remote } \\
\text { Sensing? }\end{array}$} & Yes & 45.0 \\
\hline & & No & 53.0 \\
\hline \multirow[t]{2}{*}{7} & \multirow{2}{*}{$\begin{array}{l}\text { Do you have } \\
\text { interest in training } \\
\text { on the use of } \\
\text { geospatial } \\
\text { technology }\end{array}$} & Yes & 68.0 \\
\hline & & No & 30.0 \\
\hline \multirow[t]{2}{*}{8} & \multirow{2}{*}{$\begin{array}{l}\text { Do you know } \\
\text { where you can be } \\
\text { trained } \\
\text { geospatial } \\
\text { technologies }\end{array}$} & Yes & 45.0 \\
\hline & & No & 53.0 \\
\hline
\end{tabular}

Source: Field survey, 2017

Table 5: Peoples' willingness to pay for training in geospatial literacy aid technology

\begin{tabular}{|c|c|c|c|}
\hline $\mathrm{S} / \mathrm{N}$ & Questions & Response & $\begin{array}{l}\%(\mathrm{n}= \\
152)\end{array}$ \\
\hline \multirow[t]{2}{*}{1} & \multirow{2}{*}{$\begin{array}{l}\text { Are you willing to } \\
\text { pay for the training } \\
\text { on how to read } \\
\text { Maps? }\end{array}$} & Yes & 68.0 \\
\hline & & No & 30.0 \\
\hline \multirow[t]{2}{*}{2} & \multirow{2}{*}{$\begin{array}{l}\text { Are you willing to } \\
\text { pay for the training } \\
\text { on the use of GPS } \\
\text { technology? }\end{array}$} & Yes & 64.0 \\
\hline & & No & 34.0 \\
\hline \multirow[t]{2}{*}{3} & \multirow[b]{2}{*}{$\begin{array}{l}\text { Are you willing to } \\
\text { pay for the training } \\
\text { in Geographical } \\
\text { Information } \\
\text { Systems and } \\
\text { Remote Sensing? }\end{array}$} & Yes & 62.0 \\
\hline & & No & 36.0 \\
\hline 4 & & Yes & 63.0 \\
\hline
\end{tabular}




\begin{tabular}{|l|l|l|l|}
\hline $\begin{array}{l}\text { Are you willing to } \\
\text { pay for the training } \\
\text { in geospatial } \\
\text { technologies? }\end{array}$ & No & 35.0 \\
\hline
\end{tabular}

Source: Field survey, 2017

\subsection{Challenges confronting the people in their use of geospatial literacy aid technologies}

The people interviewed were asked about the challenges facing them in their use of geospatial literacy aid technologies. Table 6 shows the results of the analysis of their responses. The table shows that top on the list of the challenges facing them in their use of smart city related technological innovations was electricity (power supply) problem/low battery capacity of the cell phones and of the personal computers/Laptops (78.0\%), followed by lack of finance to buy cell phone and personal computers that can browse/lack of finance to pay for training in geospatial technologies $(55.0 \%)$, lack of understanding of map terminology/did not understand how to read map (28.0\%), lack of personal computer/laptop (26.0\%), lack of cell phone that can browse $(24.0 \%)$, and that the methods are too technical $(24.0 \%)$.

Table 6: Challenges facing the people

\begin{tabular}{|c|c|c|}
\hline Question & Response & $\begin{array}{l}\%(\mathrm{n} \\
= \\
152)\end{array}$ \\
\hline \multirow{7}{*}{$\begin{array}{l}\text { What are the } \\
\text { challenges you } \\
\text { face in your } \\
\text { attempt to use } \\
\text { geospatial } \\
\text { technologies? }\end{array}$} & $\begin{array}{l}\text { Lack of cell phone that } \\
\text { can browse }\end{array}$ & 24.0 \\
\hline & $\begin{array}{l}\text { Lack of personal } \\
\text { computer/Laptop }\end{array}$ & 26.0 \\
\hline & $\begin{array}{l}\text { Electricity } \\
\text { supply) problem/Low } \\
\text { battery capacity of the } \\
\text { cell phone and of the } \\
\text { personal } \\
\text { computer/Laptop }\end{array}$ & 78.0 \\
\hline & $\begin{array}{l}\text { Lack of finance to buy } \\
\text { cell phone and personal } \\
\text { computer that can } \\
\text { browse/ Lack of finance } \\
\text { to pay for training in } \\
\text { geospatial technologies }\end{array}$ & 55.0 \\
\hline & It is too technical & 24.0 \\
\hline & $\begin{array}{l}\text { Lack of understanding of } \\
\text { map terminology/Did not } \\
\text { understand how to read } \\
\text { map }\end{array}$ & 28.0 \\
\hline & Others & 0.0 \\
\hline
\end{tabular}

Source: Field survey, 2017

\section{Conclusion}

The study shows people's knowledge of computer, cell phone and internet. Majority of the people interviewed were computer literate and had personal
computers/Laptops. Some of them had been using personal computers/Laptops for more than 6 years. Most of them had used their personal computers/Laptops for word processing (typing) purpose and to browse the internet. Majority of them know how to browse the internet with personal computer/Laptop. Majority of them had cell phones. Most of them had been using cell phones for more than 6 years. Majority of them were aware that some cell phones can browse the internet and know how to browse the internet with cell phones. They also had cell phones that can browse the internet.

On people's awareness of geospatial literacy aid technologies, the study shows that majority of the people interviewed were aware of maps, know how to read maps, aware of the existence of maps on the internet, and had browsed maps on the internet. While few of them browse maps on the internet daily, most of them browse maps on the internet occasionally. Most of them were aware of Google Maps, followed by Google Earth, and Bing Maps. Also most of them were aware of Global Positioning System (GPS) and the use of GPS. Furthermore, most of them were aware of Geographical Information Systems (GIS) and Remote Sensing technologies.

On people's practical applications of geospatial literacy aid technologies, findings revealed that most of the people interviewed used their personal computers/Laptops to search for location on the internet, and to search for direction to places on the internet. Majority of the respondents had browsed the internet to get location of places, had browsed the internet to get direction to places, and had browsed the internet to get distance to places. Majority of them had used their cell phone to make phone calls, and to browse the internet. Some of them had used their cell phones to get location of places, to get direction to places, and to get distance to places. Majority of them had used maps. Most of them had browsed and used Google Maps, followed by Bing Maps, and Google Earth. Most of them had used cell phones to browse maps on the internet and also most of them had used computers/Laptops to browse maps on the internet.

On people's willingness in learning more on using geospatial literacy aid technologies the study shows that majority of them had interest to learn more about how to read maps, had interest to learn more on how to use GPS technology, had interest to be trained in Geographical Information Systems (GIS)/Remote Sensing, and had interest to be trained in geospatial technologies. Some of them said that they did not know where they can be trained on how to learn more on map reading, on the use of GPS technology, on GIS/Remote Sensing, and on geospatial technologies. Most of them were willing to pay for training in geospatial technology. Some challenges they faced were: electricity (power supply) problem and low battery capacity of the cell phone and personal computer/Laptop, lack of finance to pay for the training and to buy cell phones and computers that can browse the internet.

In order to enhance human capacity building in the use and development of geospatial literacy aid technologies there is the need for improvement in electricity (power supply). Also, government should provide enabling environment 
for geospatial technology firms to operate and provide incentives for government workers for training/re-training programmes in geospatial technologies. Geospatial technology firms need to intensify the awareness raising of their products and services and also provide their services/products and training at affordable rates.

\section{Acknowledgment}

The author wishes to appreciate the effort of Mr. Akinola Ishaq Enitan a doctoral student in the Department of Urban and Regional Planning, University of Ibadan, Ibadan, Nigeria, who assisted in the field survey.

\section{References}

Bednarz S.W., Kemp K., (2011). Understanding and nurturing spatial literacy. Procedia Social and Behavioral Sciences, 21: 18-23.

Dangermond J., (2011). 'GIS: A language for understanding'. A keynote presentation at the 2011 ESRI International User Conference in San Diego, California, July 11-15, 2011 ARCNEWS Esri Fall Vol. 33, No. 3 p. 1, 7.

Edelson C. D. The challenges of defining Geo-Literacy in Essays on Geography and GIS. ESRI, Vol. 4, pp. 39-41, www.esri.com

Edelson C. D. Geographic Literacy in U.S. by 2025 "Geo Learning" in Essays on Geography and GIS. ESRI, Vol. 2, pp. 75-78, www.esri.com

NRC (National Research Council), (2006). Learning to think spatially. Washington DC: National Academies Press.

Wakabayashi Y., Ishikawa T., (2011). "Spatial thinking in geographic information science: a review of past studies and prospects for the future". Procedia Social and Behavioral Sciences 21:304313 